\title{
CORRESPONDENCE.
}

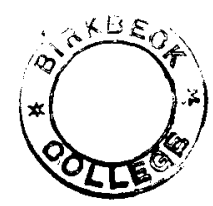

CAMBRIAN ROCKS NEAR THE WREKIN.

SIR,-In the course of the Geological Survey of Sheet 152 New Series (Shrewsbury), I have had occasion to examine the district lying between the Wrekin and Charlton Hill and have found some new exposures of Cambrian beds. The results so far obtained may be of interest.

The area in question lies between the north-eastward continuation of the Church Stretton Fault and the Wrekin Fault. It is drained by Dryton Brook and its tributary Rushton Brook.

The basal Cambrian quartzite is well known to crop out at Charlton Hill and at Rushton, between that hill and the Wrejkin. Its outcrop has now been traced through the intervening ground, and is found to be broken by a number of transverse faults. The quartzite is succeeded by about 500 feet of Comley Sandstone, the upper part of which is well exposed in a gully at the head of Dryton Brook, and here the Callavia Sandstone and overlying Olenellus Limestone, both abundantly fossiliferous, have been detected. There are also indications of several other fossiliferous Lower Cambrian horizons comparable with those worked out by Mr. E. S. Cobbold in the Comley area.

These beds are overlain by Middle Cambrian glauconitic grits and shales, in which a calcareous band, exposed in Rushton Brook, has yielded a well-preserved Paradoxidian fauna. The grits crop out also round the southern end of Charlton Hill.

Along the east flank of Charlton Hill some dark shales yield Cambrian brachiopods and ostracods; but their position in the sequence is at present obscure. Other shales with brachiopods are in contact with glauconitic grit between Upper Dryton Brook and Rushton Brook.

Shineton shales are exposed farther down stream, just north of the outcrop of the Coal Measures of the Dryton Coalfield.

It is proposed to make a more detailed examination of this area next year; meanwhile Mr. Cobbold is studying the fossils already obtained.

28 JERMYN STREET, S.W. 1.

R. W. Pocock.

16th November, 1927.

\section{CLIMATIC CORRELATION OF RAISED BEACHES.}

Sir,--The letter by Mr. W. B. Wright, in your November issue, on the subject of Raised Beaches is most interesting, and I wish to thank him for his valuable criticism and advice.

In reply, I would like to make the following comments :-

(1) The conclusions which I reached in my paper refer essentially 
to the particular raised beach sections discussed there, and much further work is admittedly necessary before a very general application can be made.

The following facts, however, seem quite plain, whatever their meaning may be.

That in the unglaciated parts of southern England there are certainly two raised beaches which resemble the $10 \mathrm{ft}$. pre-glacial beach in that they maintain a constant level over a large area, but they differ from that beach by being at the heights of $30 \mathrm{ft}$. and $60 \mathrm{ft}$.

The $60 \mathrm{ft}$. beach contains a markedly warm fauna with glacial erratics, which presumably were derived from earlier glacial deposits.

The $30 \mathrm{ft}$. beach overlies the lower part of the $60 \mathrm{ft}$. beach, and presumably is younger than it. None of these beaches can be correlated with the $10 \mathrm{ft}$. pre-glacial beach.

It is not, therefore, Mr. Wright's $10 \mathrm{ft}$. pre-glacial beach which has been correlated with the Scottish beaches, but these later deposits occurring with the pre-glacial beach in the same area.

The $30 \mathrm{ft}$. and $60 \mathrm{ft}$. beaches are, in my opinion, present in Gower, where they contain (as they do elsewhere), a well-marked littoral fauna; and thus also do they differ from the $10 \mathrm{ft}$. preglacial beach which, I understand from Mr. Wright's work, contains no fauna.

(2) Mr. Hinxman suggests in his paper that at the head of Loch Torridon, and elsewhere in Scotland, there is evidence of a readvance of the valley-glaciers " after the appearance of Neolithic man in Scotland "(presumably after the $25 \mathrm{ft}$. raised beach).

My wording on page 436 should have read: "at least after the

(3) The question Mr. Wright raises about kitchen-middens is undoubtedly important, and the possibility of material from them being incorporated in certain collections has not been forgotten. It should be noted, moreover, that the species most used for climatic purposes are forms under $\frac{1}{4}$ inch in size.

OXFORD.

Novenber, $192 \pi$. 